\title{
ПРОЯВИ ДЕПРЕСИВНОЇ СИМПТОМАТИКИ ПРИ РІЗНИХ ВАРІАНТАХ ПЕРВИННОГО ЕПІЗОДУ БІПОЛЯРНОГО АФЕКТИВНОГО РОЗЛАДУ
}

\author{
๑Ю. І. Мисула, О. П. Венгер \\ Тернопільський національний медичний університет імені І. Я. Горбачевського МОЗ України
}

РЕзЮМЕ. Розуміння особливостей депресивної симптоматики при первинному епізоді БАР має важливе значення для виявлення, лікування та профілактики захворювання у зв'язку з тяжкістю його діагностики.

Мета - вивчити особливості депресивної симптоматики при первинному епізоді біполярного афективного розладу з урахуванням клінічного варіанта та гендерного фактора.

Матеріал і методи. Клінічно обстежено 130 чоловіків та 176 жінок із первинним епізодом біполярного афективного розладу.

Результати. Встановлено, що при депресивному варіанті первинного епізоду БАР наявний весь спектр депресивної симптоматики: знижений настрій (100,0 \%), ангедонія - у 40,3 \% всіх хворих, у 40,9 \% чоловіків, і в 40,0 \% жінок, підвищена втомлюваність - відповідно 68,1 \%, 65,9 \%, і 69,3 \%, песимістичне мислення - 100,0 \%, почуття провини, марності, тривоги або страху - 33,6 \%, 36,4 \%, і 32,0 \%, занижена самооцінка - 89,1 \%, 84,1 \%, і 92,0 \%, нездатність концентруватися і приймати рішення - 45,4 \%, 36,4 \%, і 50,7 \%, думки про смерть або самогубство 79,8 \%, 79,5 \%, і 80,0 \%, нестабільний апетит, зміна ваги - 61,3\%, 59,1\%, і 62,7 \%, дисомнії - 98,3 \%, 97,7 \%, і 98,7 \%. При маніакальному варіанті наявні окремі симптоми: почуття тривоги або страху - 52,2 \%, 66,7 \%, 25,0 \%, нездатність концентруватися і приймати рішення - 56,5 \%, 46,7 \%, 75,0 \%, думки про смерть або самогубство - 8,7 \%, 6,7 \%, і 12,5 \%, дисомнії - 30,4 \%, 26,7 \%, і 37,5 \%. Змішаний варіант ближчий до депресивного, але поширеність депресивної симптоматики менша: знижений настрій виявлений відповідно у 81,8 \%, 83,3 \%, і 80,0 \%, ангедонія 45,5 \%, 66,7 \%, і 20,0 \%, підвищена втомлюваність - 54,5 \%, 50,0 \%, і 60,0 \%, песимізм - 81,8 \%, 83,3 \%, і 80,0 \%, почуття провини, марності, тривоги або страху $-72,7 \%, 66,7 \%$, i 80,0 \%, знижена самооцінка - 81,8 \%, 83,3\%, і 80,0 \%, нездатність концентруватися і приймати рішення - 72,7 \%, 83,3 \%, і 60,0 \%, думки про смерть або самогубство 63,6 \%, 50,0 \%, і 80,0 \%, нестабільний апетит, зміна ваги - 27,3 \%, 16,7 \%, і 40,0 \%, дисомнії - 100,0 \%. Значущих відмінностей у поширеності депресивної симптоматики між чоловіками і жінками не виявлено.

Висновки. Відмінності у поширеності клінічних проявів депресії при первинному епізоді біполярного афективного розладу визначаються його клінічним варіантом; вплив гендерного фактора на них $є$ несуттєвим.

КЛючОВІ СлОВА: біполярний афективний розлад; первинний епізод; депресивний епізод.

Вступ. Біполярний афективний розлад (БАР) $\epsilon$ однією з найскладніших і найактуальніших проблем сучасної психіатричної науки і практики [1-3]. Захворювання на БАР характеризується хронічним перебігом, вираженою коморбідністю, підвищеною залежністю від психоактивних речовин, скороченням тривалості життя хворих, високим рівнем смертності від супутніх соматичних захворювань і нещасних випадків, а також високим рівнем суїцидальної активності серед хворих [4-7].

Виняткове значення для повноцінного і якісного лікування БАР має своєчасна діагностика захворювання на ініціальному його етапі. Особливості клінічного перебігу БАР значною мірою визначаються характеристиками його первинного епізоду (ПЕ), при цьому особливості ПЕ можуть розглядатися як предиктори тяжкості захворювання, функціональних наслідків та відповіді на лікування [5-7]. Водночас особливості ПЕ БАР залишаються недостатньо вивченими, а низька прогностична цінність існуючих предикторів вимагає удосконалення інструментів продромальної ідентифікації $[8,9]$. Особливо це стосується депресивної симптоматики, яка, як правило, не розпізнається як можливий прояв БАР, тому знання її особли- востей $\epsilon$ важливим елементом при розробці прогностичних, профілактичних та лікувально-реабілітаційних заходів [10].

Мета - вивчення особливостей симптоматики депресії при первинному епізоді біполярного афективного розладу з урахуванням гендерного фактора та клінічного варіанта первинного епізоду.

Матеріал і методи дослідження. 3 дотриманням принципів біомедичної етики на підставі інформованої згоди нами було клінічно обстежено 306 хворих (130 чоловіків та 176 жінок) із первинним епізодом БАР, які перебували на лікуванні у Тернопільській обласній психоневрологічній лікарні у період 2011-2019 років. Середній вік обстежених пацієнтів на момент виникнення симптоматики склав $(21,3 \pm 6,5)$ років (медіана 19,0 років, інтерквартильний діапазон 17,0-22,0 роки), чоловіків $(20,5 \pm 5,8)$ років (18,0 років, 17,0-21,0 рік), жінок $(21,9 \pm 6,9)$ років (19,0 років, $18,5-22,5$ року); вік на момент звернення за медичною допомогою і обстеження - відповідно $(21,4 \pm 6,4)$ років $(19,0$ років, $18,0-$

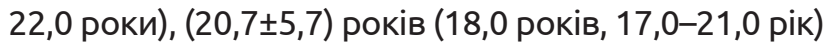
та $(22,0 \pm 6,9)$ років (19,0 років, 18,5-22,5 року).

Обстежених чоловіків і жінок ми поділили на три групи залежно від клінічного варіанта пере- 
Огляди літератури, оригінальні дослідження, погляд на проблему, випадок з практики, короткі повідомлення бігу ПЕ БАР: із переважанням депресивної симптоматики (депресивний варіант), чисельністю 119 осіб (44 чоловіки і 75 жінок); із переважанням маніакальної або гіпоманіакальної симптоматики (маніакальний варіант), чисельністю 23 особи (15 чоловіків і 8 жінок), та з одночасною наявністю депресивної та маніакальної симптоматики або зі швидкою зміною фаз (змішаний варіант), чисельністю 11 осіб (6 чоловіків і 5 жінок).

Аналіз клінічної симптоматики депресії здійснювали відповідно до критеріїв Міжнародної класифікації хвороб 10-го перегляду (MKX-10).

Статистичний аналіз проведено з використанням точного критерію Фішера. Прийнятним вважався рівень статистичної значущості розбіжностей понад 95,0\% ( $<<0,05)$.

Результати й обговорення. Аналіз депресивної симптоматики при первинному епізоді БАР з урахуванням клінічного варіанта дебюту захворювання дозволив виявити ряд закономірностей.

Структура симптоматики депресії при депресивному варіанті ПЕ БАР представлена на рисунку 1.

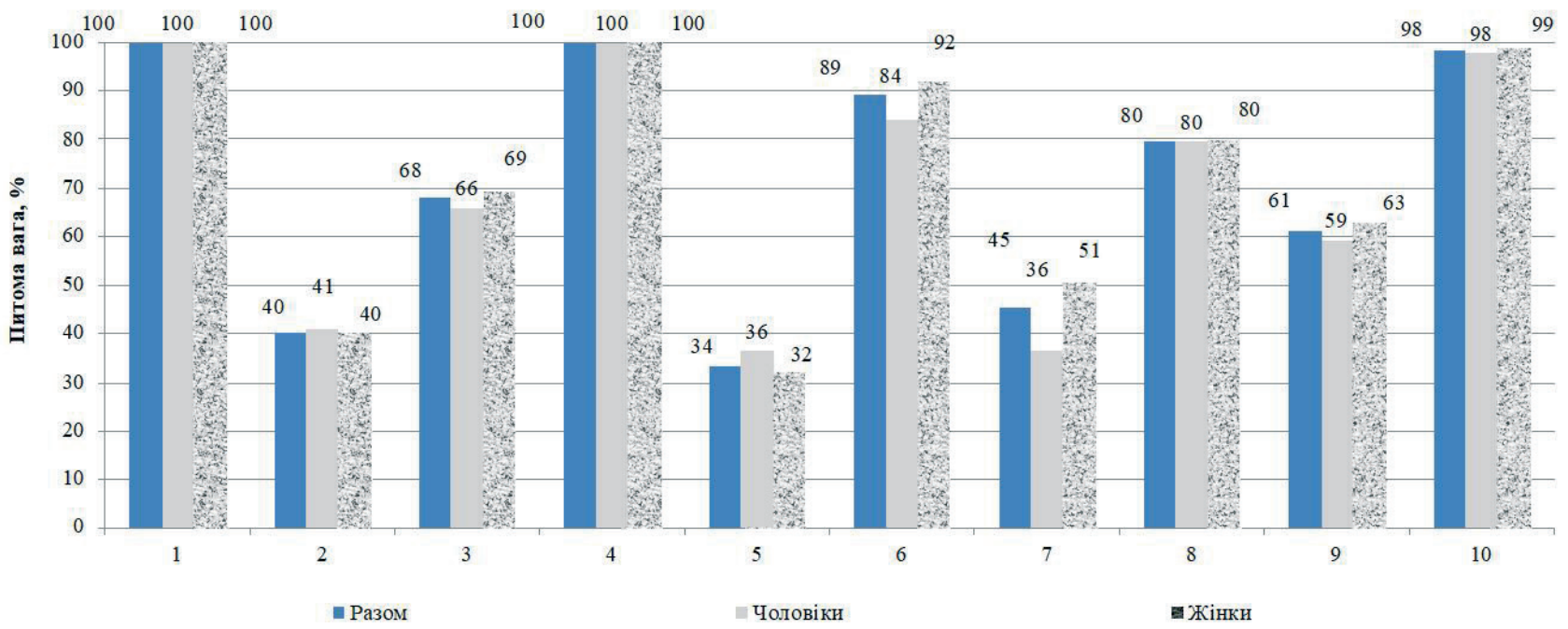

1 - знижений настрій; 2 - ангедонія; 3 - втомлюваність; 4 - песимізм; 5 - почуття провини, марності, тривоги, страху; 6 - занижена самооцінка; 7 - нездатність концентруватися і приймати рішення; 8 - думки про смерть чи самогубство;

9 - нестабільний апетит; 10 - порушений сон.

Рис. 1. Структура депресивної симптоматики при первинному епізоді БАР з депресивним варіантом ПЕ.

При депресивному варіанті ПЕ БАР наявний увесь спектр депресивної симптоматики відповідно до критеріїв МКХ-10. 3 основних критеріїв найпоширенішим є знижений настрій, що не залежить від обставин, протягом тривалого часу (щонайменше два тижні); цей симптом наявний у всіх хворих. Менш поширеними є втрата інтересу і здатності отримувати задоволення від діяльності, яка раніше таке задоволення приносила (ангедонія) - відповідно у 40,3 \% всіх хворих, у 40,9 \% чоловіків і у 40,0 \% жінок, а також зниження активності, енергії, здатності до діяльності, рухова загальмованість (гіпобулія та гіпокінезія) відповідно у 68,1%, 65,9 \% і 69,3 \%. 3 додаткових критеріїв були наявні прояви песимізму (у всіх хворих), почуття провини, марності, тривоги або страху - відповідно у 33,6 \%, 36,4 \% і 32,0 \%, знижена самооцінка - відповідно у 89,1 \%, 84,1 \% і $92,0 \%$, нездатність концентруватися і приймати рішення - відповідно у 45,4 \%, 36,4 \% і 50,7 \%, думки про смерть або самогубство - відповідно у $79,8 \%, 79,5 \%$ і 80,0 \%, нестабільний апетит, зміна ваги - відповідно у 61,3 \%, 59,1 \% і 62,7 \%, а також порушений сон, безсоння або пересинання - відповідно у 98,3 \%, 97,7 \% і 98,7 \%. Розбіжності у поширеності всіх симптомів між чоловіками та жінками статистично не значущі ( $>>0,05)$.

Структура клінічної симптоматики депресії при маніакальному варіанті ПЕ БАР наведена на рисунку 2.

При маніакальному варіанті ПЕ БАР присутні лише окремі додаткові симптоми: зокрема, почуття тривоги або страху наявне у 52,2 \% всіх хворих, у 66,7 \% чоловіків і у 25,0 \% жінок, нездатність концентруватися і приймати рішення - відповідно у 56,5 \%, 46,7 \% і 75,0 \%, думки про смерть або самогубство - відповідно у 8,7 \%, 6,7 \% і 12,5 \%, порушений сон, безсоння або пересинання - у 30,4 \%, 26,7 \% і 37,5 \%. Розбіжності у поширеності цих симптомів між чоловіками та жінками статистично не значущі ( $>0,05)$.

Структура клінічної симптоматики депресії при змішаному варіанті ПЕ БАР наведена на рисунку 3. 
Огляди літератури, оригінальні дослідження, погляд на проблему, випадок з практики, короткі повідомлення

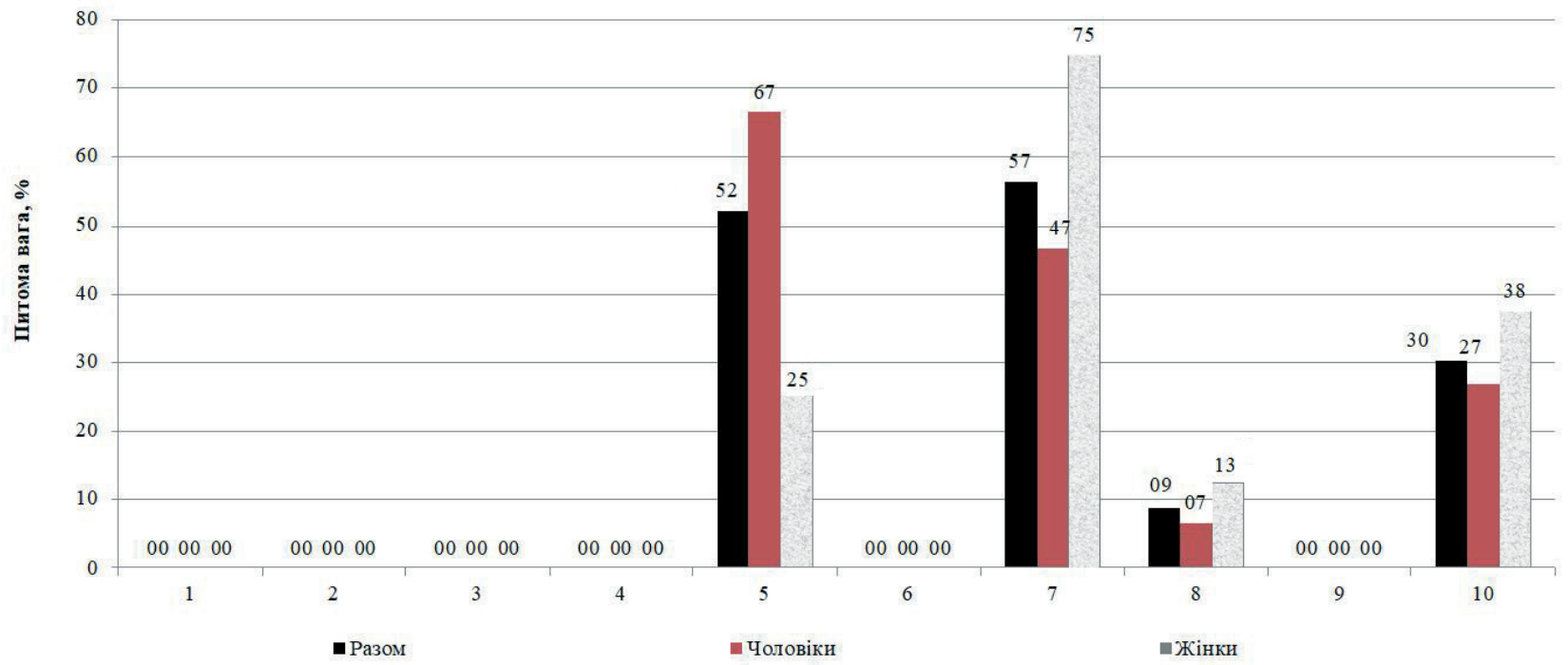

1 - знижений настрій; 2 - ангедонія; 3 - втомлюваність; 4 - песимізм; 5 - почуття провини, марності, тривоги, страху; 6 - занижена самооцінка; 7 - нездатність концентруватися і приймати рішення; 8 - думки про смерть чи самогубство; 9 - нестабільний апетит; 10 - порушений сон.

Рис. 2. Структура депресивної симптоматики при первинному епізоді БАР з депресивним варіантом ПЕ.

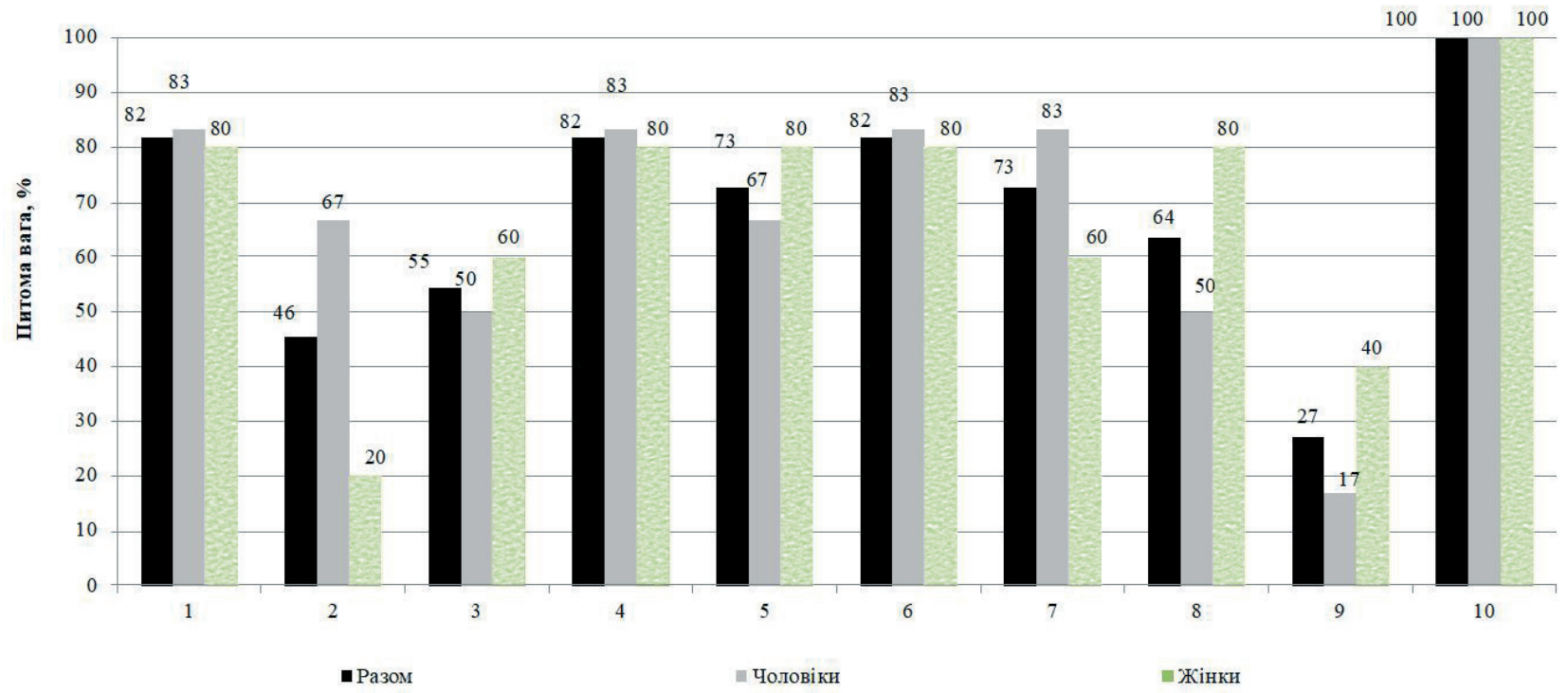

1 - знижений настрій; 2 - ангедонія; 3 - втомлюваність; 4 - песимізм; 5 - почуття провини, марності, тривоги, страху; 6 - занижена самооцінка; 7 - нездатність концентруватися і приймати рішення; 8 - думки про смерть чи самогубство; 9 - нестабільний апетит; 10 - порушений сон.

Рис. 3. Структура депресивної симптоматики при первинному епізоді БАР зі змішаним варіантом ПЕ.

При змішаному варіанті ПЕ БАР, як і при депресивному варіанті, наявний увесь спектр депресивної симптоматики, але поширеність її суттєво менша, ніж при депресивному варіанті ПЕ БАР. Так, 3 основних критеріїв депресії у хворих зі змішаним варіантом ПЕ БАР наявні знижений настрій - відповідно у $81,8 \%, 83,3 \%$ і 80,0 \%, ангедонія - відповідно у $45,5 \%, 66,7 \%$, і 20,0\%, і підвищена втомлюваність - відповідно у 54,5 \%, 50,0 \% і 60,0 \%. 3 додаткових критеріїв у хворих зі змішаним варіантом
ПЕ БАР виявлені песимізм - відповідно у $81,8 \%$, $83,3 \%$, і 80,0 \%, почуття провини, марності, тривоги або страху - відповідно у 72,7 \%, 66,7 \% і 80,0\%, знижена самооцінка - відповідно у 81,8 \%, 83,3 \%, і $80,0 \%$, нездатність концентруватися і приймати рішення - відповідно у 72,7 \%, 83,3 \% і 60,0 \%, думки про смерть або самогубство - відповідно у 63,6 \%, $50,0 \%$, і 80,0 \%, нестабільний апетит, зміна ваги відповідно у 27,3 \%, 16,7 \% і 40,0 \%, порушений сон, безсоння або пересинання, які виявлені у всіх хво- 
Огляди літератури, оригінальні дослідження, погляд на проблему, випадок з практики, короткі повідомлення рих. Розбіжності у поширенні всіх симптомів між чоловіками та жінками статистично не значущі $(p>0,05)$.

Статистичний аналіз розбіжностей між групами з різним клінічним варіантом дебюту виявив значущі розбіжності для зниженого настрою при порівнянні всіх груп між собою (р<0,01), для ангедонії - при порівнянні груп з депресивним і маніакальним варіантами ПЕ БАР у чоловіків $(p<0,05)$, у жінок $(p<0,01)$ та у всіх хворих разом $(p<0,01)$, груп з маніакальним і змішаним варіантами ПЕ БАР у жінок $(p<0,01)$ та у всіх хворих ( $<<0,01)$; для підвищеної втомлюваності - при порівняні груп з депресивним і маніакальним варіантами ПЕ БАР у чоловіків $(p<0,01)$, у жінок $(p<0,01)$ та у всіх хворих $(p<0,01)$; для песимізму при порівнянні всіх груп між собою $(p<0,01)$; для почуття провини, марності, тривоги або страху при порівнянні груп з депресивним і змішаним варіантами ПЕ БАР у чоловіків $(p<0,05)$, у жінок $(p<0,01)$ і у всіх хворих $(p<0,05)$; для зниженої самооцінки - при порівнянні груп із депресивним і маніакальним, а також з маніакальним і змішаним варіантами ПЕ БАР у чоловіків $(p<0,01)$, у жінок $(p<0,01)$ і всіх хворих $(p<0,01)$; для нездатності концентруватися і приймати рішення - при порівнянні груп із депресивним і змішаним варіантами у всіх хворих (р<0,05); для суїцидальних думок при порівнянні груп із депресивним і змішаним варіантами ПЕ БАР у чоловіків $(p<0,01)$, у жінок $(p<0,01)$ і у всіх хворих $(p<0,01)$, при порівнянні груп із маніакальним і змішаним варіантами ПЕ БАР у чоловіків $(p<0,05)$, у жінок $(p<0,05)$ і у всіх хворих $(p<0,05)$; для порушень апетиту - при порівнянні груп з депресивним і маніакальним варіантами ПЕ БАР у чоловіків $(p<0,01)$, у жінок $(p<0,01)$ і у всіх хворих, при порівнянні груп із де-

\section{ЛІТЕРАТУРА}

1. Marwaha S. Employment outcomes in people with bipolar disorder: a systematic review / S. Marwaha, A. Durrani, S. Singh // Acta Psychiatr. Scand. -2013. - Vol. 128 (3). P. 179-193.

2. Clinical practice guidelines for bipolar affective disorder (BPAD) in children and adolescents / S. Gautam, A. Jain, M. Gautam [et al.] // Indian J. Psychiatry. - 2019. Vol. 61 (Suppl. 2). - P. 294-305.

3. Mental health: strengthening our response // Information Bulletin of World Health Organisation. Geneva, WHO, 2018. - P. 1-28.

4. The International Society for Bipolar Disorders Task Force report on pediatric bipolar disorder: Knowledge to date and directions for future research / B. I. Goldstein, B. Birmaher, G. A. Carlson [et al.] // Bipolar Disord. 2017. - Vol. 19 (7). - P. 524-543.

пресивним і змішаним варіантами ПЕ БАР у жінок $(p<0,05)$, а також при порівнянні груп із маніакальним і змішаним варіантами ПЕ БАР у жінок $(p<0,01)$; для дисомній - при порівнянні груп із депресивним і маніакальним варіантами ПЕ БАР у чоловіків $(p<0,01)$, у жінок $(p<0,01)$ і у всіх хворих $(p<0,01)$, а також при порівнянні груп із маніакальним та змішаним варіантами ПЕ БАР у чоловіків $(p<0,05)$, у жінок $(p<0,01)$ і у всіх хворих $(p<0,01)$.

Висновки. При аналізі особливостей депресивних проявів при ПЕ БАР слід враховувати клінічний варіант ПЕ - депресивний, манікальний або змішаний. При депресивному варіанті ПЕ БАР представлений увесь спектр депресивної симптоматики з найбільшою поширеністю зниженого настрою, песимізму та дисомній, значною поширеністю зниженої самооцінки, суїцидальних думок та проявів астенії, і меншою - інших симптомів. При маніакальному варіанті ПЕ БАР наявні лише окремі другорядні симптоми депресії: найчастіше це почуття тривоги і страху, порушення концентрації уваги та дисомнії, і зрідка - думки про смерть. Змішаний варіант ПЕ БАР за клінічною симптоматикою депресії ближчий до депресивного варіанта, при ньому також присутній увесь спектр депресивної симптоматики, однак її поширеність суттєво менша. Найтиповішими для змішаного варіанта $є$ прояви дисомній, вагомими в структурі симптоматики є також вітальні і психологічні прояви депресій, а також когнітивні порушення. Гендерні відмінності у клінічних проявах депресії при ПЕ БАР виявилися незначущими.

Перспективи подальших досліджень пов'язані з використанням одержаних даних для розробки сучасних лікувально-реабілітаційних та профілактичних підходів при первинному епізоді біполярного афективного розладу.

5. A report on older-age bipolar disorder from the International Society for Bipolar Disorders Task Force / M. Sajatovic, S. A. Strejilevich, A. G. Gildengers [et al.] // Bipolar Disord. - 2015. - Vol. 17 (7). - P. 689-704.

6. Nabavi B. A lifetime prevalence of comorbidity between bipolar affective disorder and anxiety disorders: a meta-analysis of 52 interview-based studies of psychiatric population / B. Nabavi, A. J. Mitchell, D. Nuttc // EBioMedicine. - 2015. - Vol. 2 (10). - P. 1405-1419.

7. Methodological recommendations for cognition trials in bipolar disorder by the International Society for Bipolar Disorders Targeting Cognition Task Force / K. W. Miskowiak, K. E. Burdick, A. Martinez-Aran [et al.] // Bipolar Disord. - 2017. - Vol. 19 (8). - P. 614-626.

8. Baldessarini R. J. First-episode types in bipolar disorder: predictive associations with later illness / R. J. Baldes- 
Огляди літератури, оригінальні дослідження, погляд на проблему, випадок з практики, короткі повідомлення sarini, L. Tondo, C. Visioli // Acta Psychiatr. Scand. - 2014. Vol. 129 (5). - P. 383-392.

9. Clinical risk factors for bipolar disorders: a systematic review of prospective studies / G. L. Faedda, G. Serra, C. Marangoni [et al.] // J. Affect. Disord. - 2014. - Vol. 168. P. 314-321.

10. Mysula Yu. Structure of cognitive disorders in patients with primary episode of bipolar affective disorder / Yu. Mysula, O. Venger // Rom. J. Med. Pract. - 2020. - Vol. 15 (1). - P. 66-71.

\title{
REFERENCES
}

1. Marwaha, S., Durrani, A., \& Singh, S. (2013). Employment outcomes in people with bipolar disorder: a systematic review. Acta Psychiatr. Scand., 128 (3), 179-193. DOI: $10.1111 /$ acps. 12087

2. Gautam, S., Jain, A., Gautam, M., Gautam, A., \& Jagawat T. (2019). Clinical practice guidelines for bipolar affective disorder (BPAD) in children and adolescents. Indian J. Psychiatry, 61 (2), 294-305. DOI: 10.4103/psychiatry.IndianJPsychiatry_570_18

3. (2018). Mental health: strengthening our response. Information Bulletin of World Health Organisation. Geneva, WHO.

4. Goldstein, B.I., Birmaher, B., Carlson, G.A., DelBello, M.P., \& Findling, R.L. (2017) The International Society for Bipolar Disorders Task Force report on pediatric bipolar disorder: Knowledge to date and directions for future research. Bipolar Disord., 19 (7), 524-543. DOI: 10.1111/ bdi.12556

5. Sajatovic, M., Strejilevich, S.A., Gildengers, A.G., Dols, A., Al Jurdi, R.K., Forester, B.P., \& Shulman, K.I. (2015). A report on older-age bipolar disorder from the International Society for Bipolar Disorders Task Force. Bipolar Disord., 17 (7), 689-704. DOI: 10.1111/bdi.12331

6. Nabavi, B., Mitchell, A.J., \& Nuttc, D. (2015). A lifetime prevalence of comorbidity between bipolar affective disorder and anxiety disorders: a meta-analysis of 52 interview-based studies of psychiatric population. EBioMedicine, 2 (10), 1405-1419. DOI: 10.1016/j.ebiom.2015.09.006

7. Miskowiak, K.W., Burdick, K.E., Martinez-Aran, A., Bonnin, C.M., \& Bowie, C.R. (2017). Methodological recommendations for cognition trials in bipolar disorder by the International Society for Bipolar Disorders Targeting Cognition Task Force. Bipolar Disord., 19 (8), 614-626. DOI: $10.1111 /$ bdi.12534

8. Baldessarini, R.J., Tondo, L., \& Visioli, C. (2014). Firstepisode types in bipolar disorder: predictive associations with later illness. Acta Psychiatr. Scand., 129 (5), 383-392. DOI: $10.1111 /$ acps. 12204

9. Faedda, G.L., Serra, G., Marangoni, C., Salvatore, P., Sani, G., Vázquez, G.H., \& Koukopoulos, A. (2014). Clinical risk factors for bipolar disorders: a systematic review of prospective studies. J. Affect. Disord., 168, 314-321. DOI: 10.1016/j.jad.2014.07.013

10. Mysula, Yu., \& Venger, O. (2020). Structure of cognitive disorders in patients with primary episode of bipolar affective disorder. Rom. J. Med. Pract., 15 (1), 66-71.

\section{ПРОЯВЛЕНИЯ ДЕПРЕССИВНОЙ СИМПТОМАТИКИ ПРИ РАЗЛИЧНЫХ ВАРИАНТАХ ПЕРВИЧНОГО ЭПИЗОДА БИПОЛЯРНОГО АФФЕКТИВНОГО РАССТРОЙСТВА}

\author{
○Ю. И. Мисула, Е. П. Венгер
}

\author{
Тернопольский национальный медицинский университет имени И. Я. Горбачевского МОз Украины
}

РЕЗЮМЕ. Понимание особенностей депрессивной симптоматики при первичном эпизоде БАР имеет важное значение для выявления, лечения и профилактики заболевания в связи с тяжестью его диагностики.

Цель - изучить особенности депрессивной симптоматики при первичном эпизоде биполярного аффективного расстройства с учетом клинического варианта и гендерного фактора.

Материал и методы. Клинически обследовано 130 мужчин и 176 женщин с первичным эпизодом биполярного аффективного расстройства.

Результаты. Установлено, что при депрессивном варианте первичного эпизода БАР наблюдается весь спектр депрессивной симптоматики: сниженное настроение (100,0\%), ангедония - у 40,3\% всех 6ольных, у 40,9\% мужчин и у 40,0 \% женщин, повышенная утомляемость - соответственно 68,1 \%, 65,9 \% и 69,3 \%, пессимистическое мышление - 100,0 \%, чувство вины, бесполезности, тревоги или страха - 33,6 \%, 36,4 \% и 32,0\%, сниженная самооценка - 89,1 \%, 84,1 \% и 92,0 \%, неспособность концентрироваться и принимать решения - 45,4 \%, 36,4 \% и $50,7 \%$, мысли о смерти или самоубийстве - 79,8 \%, 79,5 \% и 80,0\%, нестабильный аппетит, изменения веса 61,3 \%, 59,1 \% и 62,7 \%, диссомнии - 98,3 \%, 97,7 \% и 98,7 \%. При маниакальном варианте присутствуют отдельные симптомы: чувство тревоги или страха - 52,2 \%, 66,7 \%, 25,0\%, неспособность концентрироваться и принимать решения - 56,5 \%, 46,7 \%, 75,0 \%, мысли о смерти или самоубийстве - 8,7 \%, 6,7 \% и 12,5 \%, диссомнии - 30,4 \%, 26,7 \% и 37,5 \%. Смешанный вариант ближе к депрессивному, но распространенность депрессивной симптоматики меньше: сниженное настроение обнаружено соответственно у 81,8 \%, 83,3 \% и 80,0 \%, ангедония - 45,5\%, $66,7 \%$ и $20,0 \%$, повышенная утомляемость $-54,5 \%, 50,0 \%$ и 60,0 \%, пессимизм $-81,8 \%, 83,3 \%$ и 80,0 \%, чувство 
Огляди літератури, оригінальні дослідження, погляд на проблему, випадок з практики, короткі повідомлення вины, бесполезности, тревоги или страха $-72,7 \%, 66,7 \%$ и 80,0 \%, сниженная самооценка - 81,8 \%, 83,3 \% и 80,0 \%, неспособность сконцентрироваться и принимать решения - 72,7 \%, 83,3 \% и 600 \%, мысли о смерти или самоубийстве $-63,6 \%, 50,0 \%$ и 80,0 \%, нестабильный аппетит, изменения веса - 27,3 \%, 16,7 \% и 40,0 \%, диссомнии $100,0 \%$. Значимых различий в распространенности депрессивной симптоматики между мужчинами и женщинами не выявлено.

Выводы. Различия в распространенности клинических проявлений депрессии при первичном эпизоде биполярного аффективного расстройства определяются его клиническим вариантом; влияние гендерного фактора на них несущественно.

КЛЮЧЕВЫЕ СЛОВА: биполярное аффективное расстройство; первичный эпизод; депрессивный эпизод.

\section{MANIFESTATIONS OF DEPRESSIVE SYMPTOMS IN DIFFERENT VARIANTS OF THE PRIMARY EPISODE OF BIPOLAR DISORDER}

\section{Horbachevsky Ternopil National Medical University \\ ๑Yu. I. Mysula, O. P. Venger}

SUMMARY. The study of the clinical features of depression in the primary episode of bipolar affective disorder is important for the timely detection, treatment and prevention of disease.

The aim - to study the features of the symptoms of depression in the primary episode of bipolar affective disorder, taking into account the gender factor and clinical variant.

Material and Methods: We have clinically examined 130 men and 176 women diagnosed with bipolar affective disorder.

Results. In the depressive variant the whole spectrum of depressive symptoms is present: low mood (100.0 \%), anhedonia - in $40.3 \%$ of all patients, $40.9 \%$ of men, and $40.0 \%$ of women, fatigue $-68.1 \%, 65.9 \%$, and $69.3 \%$, pessimism $100.0 \%$, feelings of guilt, needlessness, anxiety or fear $-33.6 \%, 36.4 \%$, and $32.0 \%$, low self-esteem $-89.1 \%, 84.1 \%$, and $92.0 \%$, inability to concentrate and make decisions $-45.4 \%, 36.4 \%$, and $50.7 \%$, thoughts of death or suicide $79.8 \%, 79.5 \%$ and $80.0 \%$, unstable appetite, weight change $-61.3 \%, 59.1 \%$, and $62.7 \%$, dyssomnia $-98.3 \%, 97.7 \%$, and $98.7 \%$. In the manic variant there are some symptoms: anxiety or fear $-52.2 \%, 66.7 \%, 25.0 \%$, inability to concentrate and make decisions - $56.5 \%, 46.7 \%, 75.0 \%$, thoughts about death or suicide $-8.7 \%, 6.7 \%$, and $12.5 \%$, dyssomnia $-30.4 \%, 26.7 \%$, and $37.5 \%$. The mixed variant is closer to depressive, but the prevalence of depressive symptoms is lower: the decreased mood was found in $81.8 \%, 83.3 \%$, and $80.0 \%$, anhedonia $-45.5 \%, 66.7 \%$, and $20.0 \%$, fatigue $54.5 \%, 50.0 \%$, and $60.0 \%$, pessimism $-81.8 \%, 83.3 \%$, and $80.0 \%$, feelings of guilt, futility, anxiety or fear $-72.7 \%$, $66.7 \%$, and $80.0 \%$, low self-esteem $-81.8 \%, 83.3 \%$, and $80.0 \%$, inability to concentrate and make decisions - $72.7 \%$, $83.3 \%$, and $60,0 \%$, thoughts of death or suicide $-63.6 \%, 50.0 \%$, and $80.0 \%$, unstable appetite, weight change $-27.3 \%$, $16.7 \%$, and $40.0 \%$, dyssomnia - $100.0 \%$. However, no significant differences were found in the prevalence of depressive symptoms between men and women.

Conclusions: differences in the prevalence of clinical manifestations of depression in the primary episode of bipolar affective disorder are determined by the clinical variant; the impact of gender on them is insignificant.

KEY WORDS: bipolar affective disorder; primary episode; depressive episode. 